«Філософія та політологія в контексті сучасної культури», 2020, Т. 12, Вип. 1(25)

ФІЛОСОФІЯ ТА ПОЛІТОЛОГІЯ В КОНТЕКСТІ СУЧАСНОЇ КУЛЬТУРИ

ISSN 2663-0265 (print) ISSN 2663-0273 (online)

2020. Vol. 12. Issue 1.

Journal home page: https://fip.dp.ua/index.php/FIP

Дар'я Сергіївна Вілкова

Інститут міжнародних відносин

Київського національного університету

імені Тараса Шевченка,

вул. Іллєнка, 36, Київ, 04119, Україна

УДК 327.5

\title{
МІЖНАРОДНІ ВІДНОСИНИ
}

Daria Vilkova

Institute of International Relations,

Taras Shevchenko National University of Kyiv,

36 Illenko St., Kyiv, 04119,

Ukraine

E-mail: vydelkova@gmail.com, ORCID ID: https://orcid.org/0000-0001-5384-6884

\section{ПОНЯТТЯ СЛАБКИХ ДЕРЖАВ ЯК ВІДПОВІДЬ}

НА ЗАГРОЗИ МІЖНАРОДНІЙ БЕЗПЕЦІ

Received 28 April 2020; revised 20 May 2020; accepted 10 June 2020

DOI: $10.15421 / 352019$

\section{Анотація}

Автор досліджує проблему кореляиії введеного в ужиток у 1990-х поняття, що характеризує слабкість держав на міжнародній арені з транснаціональними загрозами системі міжнародної безпеки. Серед ключових завдань є визначення загроз, що постали перед міжнародною спільнотою у ХХІ столітті, аналіз зв'язку між ними та загрозами безпеці, щз не поважають кордонів. Ключове питання статті полягає в тому, чи можна вважати введення поняття в академічний дискурс та зовнішньополітичні кроки різних акторів відповіддю на транснаціональні загрози. Автор аналізує ряд матеріалів, присвячених таким питанням, як трансначіональний тероризм, поширення зброї, гуманітарні загрози, зокрема в системі охорони здоров'я та довкілля. Також дослідниия прослідковує зв'язок між ефектами переливання загроз, політичного насилля та конфліктів зі слабких держав y регіон, відтак окреслюючи їх влив на регіональну та міжнародну безпеку. Як висновок, автор стверджує, що формування, еволючія та популяризація поняття слабких держав є оперативною відповіддю на транснаціональні загрози системі міжснародної безпеки, щэо особливо актуалізувалися у 1990-2010х роках, паралельно з процесами глобалізації в міжнародній спільноті.

Ключові слова: слабкі держави, транснаціональні загрози, ефект переливання, міжнародна безпека.

\section{Fragile states concept as a response to international security threats}

\section{Abstract}

The author explores the problem of correlation of the concept introduced in the 1990s, which characterizes the weakness of so-called fragile states in the international arena with different global security issues. The particular focus is on the impact that transnational threats coming from such weak actors have onto the international security system. The key aims of the article are identifying the threats posed to the international community in the 21st century, as well as analyzing the link between them and the contexts of fragile states where governments are not able to provide proper execution of the basic state functions. The main question this article answers is as follows - whether introducing the concept into the academic discourse and foreign policy agenda of different actors, such as the United States or the United Kingdom and a number of international organizations, such as the World Bank or OECD, can be considered a response to transnational threats to the international security system. The author analyzes a number of materials focused on transnational terrorism, weapon proliferation, humanitarian threats, including those related to the environmental issues and health security systems. The researcher also traces the link between the effects of spillover effect with regard to political violence and conflicts in fragile states outlining their impact on regional and international security. In conclusion, the author argues that the formation, evolution and popularization of the notion of fragile states is an operational response to transnational threats to the international security system, which were particularly relevant in the 1990s and 2010s emerging in parallel with globalization processes in the international community.

Keywords: fragile states, transnational threats, spillover effect, international security. 


\section{Понятие слабых государств как ответ на угрозы международной безопасности}

\section{Аннотация}

Автор исследует проблему корреляиии введенного в обиход в 1990-х понятия, характеризующего слабостьгосударствнамеждународнойаренестранснациональнымиугрозамисистемемеждународной безопасности. Среди ключевых задач является определение угроз, стоящих перед международным сообществом в ХХІ веке, анализ связи между слабыми государствами и транснациональными угрозами. Ключевой вопрос статьи заключается в том, можно ли считать введение понятия в академический дискурс и внешнеполитические концепции различных акторов ответом на транснациональные угрозы. Автор анализирует ряд материалов, посвященных таким вопросам, как транснациональный терроризм, распространение оружия, гуманитарные угрозы, в частности в системе здравоохранения и зашиты окружающей среды. Также исследовательница прослеживает связь между эффектами переливания угроз, политического насилия и конфликтов из слабых государств в регионы, очерчивая влияние таких стран на региональную и международную безопасность. Как вывод, автор утверждает, что формирование, эволючия и популяризачия понятия слабые государства является оперативным ответом на транснациональные угрозы системе международной безопасности, которые особенно актуализировались в 1990-2010x годах, параллельно с процессами глобализации в международном сообществе.

Ключевые слова: слабые государства, транснациональные угрозы, эффект переливания, международная безопасность.

Постановка проблеми у загальному вигляді та зв'язок із важливими науковими чи практичними завданнями.

Початок нового століття ознаменувався низкою знакових подій для архітектури міжнародної безпеки в цілому. Саме на турбулентні десятиліття 1990-х та 2000-них припала публікація основоположних творів, які окреслили порядок денний на десятиліття. Від зіткнення цивілізацій за С.Хантінгтоном до «кінця історії» Ф.Фукуями, дослідники шукали нові концепти та дискурси в міжнародних відносинах після закінчення Холодної війни.

Саме зміна структури системи міжнародної безпеки та й світопорядку загалом спричинила також появу менш відомих, швидше «оперативних» понять. Одним 3 них можна вважати популяризований у статті «Foreign Policy» дослідниками С.Хелманом та Х.Ратнером концепт, що після довготривалих трансформацій поняття нині називають слабкими державами [13, с.3].

Спершу поняття стосувалося таких категорій країн, як непередбачувані партнери - ряд держав, що з'явилися на політичній мапі світу внаслідок розпаду СРСР, а пізніше і Югославії, а також таких акторів міжнародних відносин, де держава була неспроможна виконувати функції, почасти внаслідок конфліктів. Згодом, поняття трансформувалося в те, що нині позначається як слабкі контексти, і стало корелюватися 3 так званими транснаціональними загрозами міжнародній безпеці.

Пік популярності поняття припав на період після 2001 року, коли було здійснено першу терористичну атаку на території Сполучених Штатів Америки. Актуалізацію та широке застосування не лише в академічних роботах, але й у риториці та основоположних документах переважно західних країн поняття набуло паралельно з підготовкою та початком операцій в Афганістані та Іраку. цій.

Аналіз останніх досліджень і публіка-

Серед ключових дослідників, які займаються проблемою слабкості держав, найвідомішими іменами є С.Патрік, Р.Ротберг, Дж. П'яцца, Д.Лісанті [20;23;21;17]. Особливу увагу фактору транснаціональних загроз, зокрема тероризму, приділяє Дж. Джордж [9]. Також вагомий доробок здійснили Ч.Колл, автор тривимірного підходу до функціонування «авторитет-спроможність-безпека», Р.Такейх і Н.Гвоздев, Р.Вайринен та інші [4;27;31]. Серед вітчизняних дослідників питання окреслювали у своїх роботах, зокрема, Л.Березинський та Л.Дорош [1;2].

Більшість дослідників концентруються на визначенні суті поняття, класифікації держав, аналізу існуючих підходів до вивчення слабких держав, індексів тощо. Ряд науковців продовжують дебати щодо доречності викори- 
стання поняття, потребі його переосмислення тощо.

Хоча є роботи, що концентруються на окремих проявах загроз системі міжнародної безпеки, як, наприклад, транснаціональний тероризм, існує потреба в дослідженні, спрямованому на визначення, чи можна вважати популяризацію поняття відповіддю на транснаціональні загрози загалом.

Мету і завдання цієї статті можна сформулювати наступним чином:

визначити ключові загрози міжнародній системі безпеки, що постали перед міжнародною спільнотою у XXI столітті;

проаналізувати зв'язок між слабкістю держав та транснаціональними загрозами, що не поважають кордонів;

дати відповідь на питання чи можна вважати введення та широкий ужиток поняття слабких держав відповіддю на певні загрози міжнародній безпеці.

\section{Ня.}

Виклад основного матеріалу досліджен-

Отож, зосередимося на першому підпункті, а саме роз'ясненні, які саме загрози міжнародній безпеці є ключовими. У цьому аспекті, одним з ключових досліджень $є$ підготований в 2006 році експертом Ради 3 міжнародних відносин С.Патріком робочий звіт. У ньому стверджується, що транснаціональні загрози, такі як хвороби, організована злочинність, енергетична нестабільність, розповсюдження зброї масового враження і тероризм мають прямий та непрямий вплив на регіональну стабільність та міжнародну безпеку [20].

3 ідеєю також погоджуються дослідники гуманітарного права з Міжнародного Комітету Червоного Хреста. Зокрема, у звіті організації за 2009 рік німецький професор міжнародного права та безпеки Р.Гайс опублікував доповідь про збройні конфлікти малої інтенсивності, ефекти переливання конфліктів зі слабких держав та спорадичні операції третіх сторін [8].

Серед іншого, йшлося про таке: «Територіальні ефекти переливання конфліктних сценаріїв зі слабких держав є доволі частим явищем. Це трапляється через те, що в таких контекстах традиційні поняття «громадян- ських воєн», демаркації території та міжнародно визнаних кордонів небагато значать для збройних угрупувань, що борються радше за економічні вигоди, аніж за зміну режиму чи контроль над урядом.» [8, с.130].

У документах британських дослідників теж знаходимо інтерес до питання негативних ефектів переливання зі слабких держав. 3окрема, йдеться про транснаціональні загрози безпеки, особливо гуманітарного характеру, серед яких ті ж таки потоки мігрантів, хвороби, поширення насилля й жорстокості, деградація навколишнього середовища та дестабілізуючий ефект на розвиток сусідніх держав.

У 2014 році відомий аналітичний центр RAND видав дослідження ефектів переливання на прикладі конфлікту в Сирії з підзаголовком «Визначення факторів, що сприяють та утримують поширення насилля〉 [33]. 3 ключових висновків зазначимо такі: зовнішня воєнна допомога, велика кількість біженців та слабкість сусідніх держав сприяє розповсюдженню насилля від громадянських воєн та заворушень. Оскільки більшість держав, які є чи були слабкими або навіть невдалими (що нині означає критичний рівень слабшання) переживали етапи громадянських воєн або інших типів збройних конфліктів, теза лише підтверджує гіпотезу про негативні ефекти переливання з таких країн.

Оскільки вищезгадане дослідження стосувалося саме Сирії, то фокус був саме на регіоні Близького Сходу в цілому. Зокрема, йшлося про те, що є висока вірогідність того, що насилля в Сирії, якщо його не регулювати та не вирішувати конфлікт здатне «перелитися» до країн сусідів, серед яких у 2014 році зазначали Йорданію та Туреччину.

Як наочні приклади було стверджено те, що «насилля вже поширилося до Лівану не без сприяння цьому Хезболли, а також продовжує сприяти сектарному конфлікту між сунітами та шиїтами в Іраку» [33, с.10]. Серед інших дестабілізуючих факторів посилення терористичних угрупувань як Аль-Каїда, Джабхатан-Нусра та інших, котрі діють переважно в прикордонних районах Іраку та Сирії - тобто, йдеться саме про загрозу транснаціонального тероризму через слабкість Сирійської Респу- 
бліки як держави.

Такий приклад було взято не лише через актуальність проблематики як в 2014 році, так і донині, а ще й через «зручність» регіону для підтвердження ідеї «переливання» у силу того, яким тісним регіоном, де країни співіснують дуже близько одна $з$ одною, є Левант зокрема та Близький Схід загалом [33].

Дослідники питання розглядають подібний ефект, притаманний слабким державам у різних аспектах. Серед них найчастіше називають, за влучним висловленням політологів 3.Ікбаля та Х.Старра, «дифузність та інфекційність» подібних контекстів [16]. У цьому сенсі центральним питанням $є$ таке: чи нестабільність, заворушення, громадянська війні чи збройний конфлікт, як і власне слабкість однієї країни призводить до схожої ситуації у сусідніх?

Дослідження згаданих політологів, видане в 2008 році швидше теоретичне, аніж емпіричне. Ними розглядаються теорії просторової дифузності політичного насилля та географічної «інфекційності» слабкості держав. Опрацьовані дані базувалися на відомому рейтингу POLITY, що готувався в період між 2005 та 2014 роком та містить інформацію про тренди політичних режимів 167 країн світу [18].

Цікаво, що спонсором проекту виступила Робоча група з політичної нестабільності, фінансована, у свою чергу, ЦРУ. Саме ця група була однією з перших, хто почав досліджувати слабкі держави ще за президентства Білла Клінтона [26].

3.Ікбаль та Х.Старр, котрі були одними 3 перших, хто взявся розглядати питання негативних ефектів переливання (у першу чергу, насилля) зі слабких держав оглядали саме групу держав, що за шкалою POLITY отримали невисоку оцінку -77 . Науковці дійшли до висновків, що певні просторові ефекти дійсно мають місце. Найчастіше саме держави, котрі мають найвищі показники слабкості, тобто $є$ невдалими, генерують послідовні заворушення, нестабільність, внутрішні конфлікти та громадянські війни в сусідніх державах [18].

До того ж, відносно «малі» форми негативних ефектів переливання, як політична нестабільність поширюються значно слабше, ніж інтенсивні форми насилля. Виокремлюючи серед опрацьованих країн та певних періодів часу регіон Субсахарської Африки, дослідники зазначають дані, що у 55\% випадків відбувалися чи досі тривають громадянські війни [19].

Отож, проміжний висновок є таким: сама по собі слабкість держави не $€$ «інфекційною», на відміну від серйозних іiі наслідків. Найбільшу увагу в статті приділено саме громадянським війнам, котрі в більшості випадків мають ефект дифузності на сусідні держави й регіони в цілому. Загалом, 3.Ікбаль та Х.Старр сфокусували увагу саме на військово-політичних наслідках випадків уже не просто слабких, а невдалих держав (failed states).

Логічно, що наступним завданням дослідники ставлять визначення шляхів мінімізації негативних загроз та ефектів, і визнають, що міжнародні організації, як ООН, Світовий Банк чи МВФ мають приділяти більше уваги державам, що знаходяться в «зоні ризику», на шляху до слабкості чи невдалості, і вчасне втручання подібних агенцій «можливо врятує від дифузності слабких держав» $[10 ; 18]$.

Дослідник С.Патрік почав 3 того, що зазначив які посадовці та агенції визнають безпосередню загрозу від негативних ефектів переливання, спричинених слабкими державами. Серед них була 68 держсекретарка США К.Райс, котра ствердила, що «держави, нездатні здійснювати «відповідальний суверенітет» мають ефекти переливання у вигляді тероризму, розповсюдження зброї та інших загроз» [20].

Схожої думки дотримувався й відомий політолог Р.Хаас, котрий у січні 2003 року говорив, що «терористичний акт 11 вересня 2001 року нагадав нам [США], що слабкі держави можуть загрожувати безпеці настільки ж, наскільки сильні державні утворення; вони створюють грунт для екстремізму та злочинців, нелегальному обігу наркотиків та терористів» [12].

В огляді 2002 року під назвою «Закордонна допомога для національних інтересів: просування свободи, безпеки та можливостей» дослідники USAID зазначали: «Коли уряд i 
обраний шлях розвитку перестають діяти в окремій державі, наслідки цього впливають на цілий регіон та становлять загрозу всьому світові. Тероризм, політичне насилля, громадянські війни, організована злочинність, інфекційні захворювання, екологічні катастрофи, потоки біженців та масова міграція переходять кордони слабких держав та є вкрай деструктивними загрозами, аніж будь-коли раніше» [30].

Та не лише в США науковці й керівні особи урядів були занепокоєні проблемою слабких держав. Подібне бачення мали прем'єр-міністр Сполученого королівства, уряди Канади, Австралії, ООН загалом. Про це свідчать створення нової Комісії з розбудови миру для допомоги поствоєнним країнам (2005 рік), ініціатива «Слабкі держави» Комітету з допомоги розвитку ОЕСР у взаємодії з програмою LICUS Світового банку $[5 ; 10 ; 30 ; 32]$.

Британська традиція досліджувати слабкі держави досі є актуальною. Так, на базі Лондонської школи економіки та Оксфордського університету в рамках діяльності Міжнародного центру з розвитку (International Growth Centre) було створено спеціальну комісію. Вона має назву Комісія зі слабкості держав та розвитку (Commission on State Fragility, Growth and Development).

Про важливість діяльності подібних інституцій зазвичай свідчить сам їх склад. Так, головою цієї комісії є прем'єр-міністр Сполученого Королівства (2010-2016 рр.) Д.Кемерон. Серед інших учасників також знані експерти з політекономії П.Колльєр, Т.Беслі, відомий експерт 3 питань суверенітету С.Краснер та ряд інших знаних дослідників.

У доповіді комісії квітня 2018 року слабкість держав розглядається як певний синдром, або ж пастку, у яку потрапляють десятки країн світу. Сам звіт орієнтований на шляхи вирішення проблеми слабкості держав. У ньому проаналізовано ряд «симптомів», характерних країнам, що опинилися в лавах слабких [6].

Для цілей цього дослідження більш цікавими є спостереження про те, який вплив такі слабкі держави мають для регіональної та міжнародної безпеки. Наводячи як прикла- ди Бурунді, Демократичну Республіку Конго, Сьєрра-Леоне, а також менш наочні приклади, де слабкість держави проявилася внаслідок серйозних шоків і затяжних конфліктів - Сирію та Лівію, автори стверджують наступне. Коли щонайменше один державний актор в регіоні переживає слабшання інституцій, то в поєднанні з затяжним конфліктом це створює локальний осередок пастки слабкості, що утворюється в регіоні. Наочним прикладом $є$ Сахель [6, с.16].

Варто зазначити, що паралельно зі згаданими вище поглядами на загрози та ефекти переливання уже в 2005 році були й менш палкі прихильники такого підходу. Серед них - науковці Прінстонського університету, котрі у звіті Робочої групи з державної безпеки та транснаціональних загроз зазначали, що «США та інші держави з високими показниками урядової та соціальної спроможності використовують концепт транснаціональних загроз, щоб відвести увагу міжнародної спільноти від самих себе». Водночас вони не заперечували, що слабкість держав 3 ядерним потенціалом, як Пакистану чи Північної Кореї здатні створити загрозу національній безпеці США [3].

Майже в усіх документах, присвячених цій тематиці йдеться про загрози розповсюдження зброї. Причому поки уряди великих держав занепокоєні ядерним питанням, наочною в багатьох регіонах $є$ проблема стрілецької, вогнепальної зброї - накопичення, нелегальних поставок тощо.

Про це свідчать дані відомого женевського Small Arms Survey - у 2015 році вони писали про 640 мільйонів одиниць такої зброї, що циркулює світом, і багато з них знаходяться в руках приватних осіб для використання в протизаконних цілях [25]. Зокрема, звіт цієї організації, як і SIPRI підіймає ряд інших питань - від знищення дикої природи саме цим видом зброї (переважно в Африці й переважно заради слонових кісток) до проблеми накопичення одиниць зброї в слабких контекстах, серед яких особливу увагу отримали постконфліктна Бурунді та Північна Малі [24; 25].

Легкодоступність вогнепальної зброї поглиблює слабкість держав, сприяє продов- 
женню й без того тривалих громадянських воєн, заворушень, спалаху злочинності, що і спостерігалося в багатьох випадках невдалих держав, серед яких Афганістан, Колумбія, Гаїті, Судан, ДРК та ряд інших.

У цьому контексті не можна не згадати також аспект експорту та імпорту такої зброї, котрі не завжди опиняються в руках офіційних легальних замовників. Серед оглядів цього питання знаходимо прикрий приклад, до якого має відношення Україна. У 1999 році було відправлено на експорт 68 тонн амуніції до Буркіна-Фасо. Звідти зброя потрапила до Ліберії і нарешті до Сьєрра-Леоне, де опинилася в руках повстанської армії «Об'єднаного народного фронту». Україна ж у затяжній громадянській війні в останній країні підтримувала протилежну сторону. Цей випадок свідчить про нестабільність і нескоординованість ситуації в слабких державах і ширших регіональних контекстах [22].

Прослідковується також «паразитичний» зв'язок між транснаціональною організованою злочинністю загалом та слабкими державами. Тенденції тут дуже схожі на ті, що притаманні транснаціонального тероризму - залежно від обраної «сфери діяльності» подібних організацій.

Зрозуміло, що фінансове шахрайство, махінації, пов'язані 3 правом інтелектуальної власності, великою мірою відмивання грошей - такі злочини 3 можливими виключеннями здійснюються переважно в невеликих офшорних фінансових центрах, розвинутих державах тощо.

Інша справа, наприклад, незаконний обіг наркотиків. Протягом декількох років згідно звітів Стратегії США у боротьбі з наркотичним обігом стверджується, що близько 90\% героїну поширюється світом 3 Афганістану. Серед ключових країн, звідки наркотики походять, або які слугують їм транзитом, зокрема, такі: знову Афганістан, Гаїті, Лаос, Мексика, Нікарагуа, Пакистан, Панама, Перу, Венесуела та ряд інших [7].

Кримінальні угрупування успішно експлуатують відсутність спроможності та ефективності слабких держав, зокрема в конфліктних зонах - Колумбія та ДРК є класичними прикладами. Більше того, конфлікти в деяких випадках - не завжди, але завжди 3 негативними наслідками - поширюються поза межі однієї держави, створюючи таким чином те, що дослідники називають «поганим оточенням».

Так трапилося в 1990-х роках у Західній Африці - Ліберія, Сьєрра-Леоне, Гвінея та Кот-Дівуар опинились в заручниках ситуації, подібне спостерігається сьогодні в регіоні Близького Сходу.

Навіть за відсутності насилля, стверджують аналітики Світового Банку, слабкість однієї держави регіону, у сенсі загального зростання, вдаряє по фінансових можливостях і перспективах сусідніх. Середні економічні втрати від потрапляння окремої держави до статусу «LICUS» - low income countries under stress (країни з низькими доходами, що перебувають у кризових ситуаціях) - для неї та сусідів нібито дорівнювали сумі в 82,4 млрд доларів, а глобальний бюджет програм 3 допомоги в рік підготовки дослідження складав 79 млрд доларів. Звісно, підрахунки є доволі умовними, однак економічна невигідність слабшання держав є очевидною, причому не лише для них самих, але для сусідів, регіонів та й світу загалом $[28 ; 32]$.

Останньою згадаємо загрозу, що складають слабкі та невдалі контексти для здоров'я громадян, особливо враховуючи актуалізацію питання сьогодні. Слабкі або й взагалі відсутні системи охорони здоров'я поряд з бідністю населення, неефективністю, неспроможністю або й відсутністю урядів, погіршення умов життя - усе це родючий грунт для появи й швидкого поширення пандемій.

Так, за останні десятиліття з'явилися десятки нових хвороб, серед яких ВІЛ/СНІД, Ебола, лихоманка Західного Нілу, а давно відомі захворювання набувають нових якостей $\mathrm{i}$ стають резистентними до існуючих ліків.

Зрозуміло, що хвороби не з'являються виключно у слабких державах світу, однак саме в таких місцях вони поширюються й перетворюються в епідемії. У силу збільшення потоків біженців з подібних держав, вони проникають у нові країни і стають глобальним лихом.

Так, у 2005 році уряд Нігерії не здійснив програму з імунізації населення, i таким чи- 
ном майже зникла хвороба поліомієліту поширилася Африкою та проникла в інші регіони. Інший приклад - сьогоднішній Смен, одна з найслабших держав світу, з дуже серйозною епідемією давно забутої у світі холери $[11 ; 15]$.

Навівши ряд прикладів транснаціональних загроз, котрі становлять слабкі держави, згадаємо наостанок слова тодішнього Генерального секретаря ООН Кофі Аннана, який у 2005 році звітував про досягнення у виконанні відомих Цілей Тисячоліття: «Якщо держави слабшають, народи світу перестають отримувати блага безпеки, розвитку та справедливості, що є їхнім правом. Таким чином, одним із головних викликів нового тисячоліття $є$ забезпечення того, щоб усі держави залишалися достатньо сильними для подолання інших викликів міжнародній спільноті» [29].

\section{Висновки.}

Відтак, переходячи до висновків цього дослідження, можна констатувати наступне. Дійсно, внаслідок посиленої глобалізації, що співпала в часі з 1990-тими та 2000-2010-тими роками, кількість транснаціональних загроз міжнародній безпеці зросла.
Особливою мірою це стосується таких факторів, як ефекти переливання політичного насилля в сусідні держави, транснаціонального тероризму та гуманітарних загроз (у першу чергу йдеться про довкілля та систему охорони здоров'я), що не поважають кордонів.

Дійсно, усі ці виклики поставали перед міжнародною спільнотою і до визначення, актуалізації та розвитку поняття слабких держав. Водночас, наявність оперативного поняття, що пройшло певний шлях еволюції протягом останніх десятиліть активно використовувалося в зовнішньополітичних документах західних країн.

Також, введення в ужиток цього концепту дозволило окреслити певні зміни в підходах до державотворення, самої ролі та функцій держави й влади в країнах.

Відтак, можна вважати доречним використання поняття, зокрема в документах організацій донорів, як USAID, Світовий банк, а також ОЕСР. Це також сприяло напрацюванню певних шляхів мінімізації транснаціональних загроз, які можуть слугувати предметом подальших наукових розвідок.

\section{Бібліографічні посилання / References}

1. Березинський, Л.В. Основні підходи до дослідження державної спроможності/неспроможності. Вісник Дніпропетровського університету, 9/2, 2012, 155-160. / Berezynsky, L. Osnovni pidhody do doslidzhennia derzhavnoyi spromozhnosti/nespromozhnosti. Visnyk Dnipropetrovskoho Universytetu, 2012, 9/2, 155-160.

2. Дорош Л. «Слабкість» держави на міжнародній арені: до проблеми визначення змісту поняття. Геополітика і міжнародні відносини, 2012, 24, 67-72. / Dorosh, L. «Slabkist» derszhavy na mizhnarodniy areni: do problemy vyznachennia zmistu poniattia. Heopolityka i mizhnarodni vidnosyny, 2012, 24, 67-72.

3. Bergen P. Report of the Working Group on state security and transnational threats. The Princeton Project of National Security. September 2005.

4. Call C. The Fallacy of the 'Failed State' «Third World Quarterly», 2008, 1491-1507.

5. Chalmers M. Spending to save? An analysis of the cost effectiveness of conflict prevention versus intervention after the onset of violent conflict. Centre for International Cooperation and Security Defence and Peace Economics, 2007, 18(1), 1-23.

6. Commission of State Fragility, International Growth and Development. Escaping the fragility trap. April 2018. Retrieved from https://www.theigc.org/wp-content/uploads/2018/04/Escaping-the-fragility-trap. pdf

7. Department of State. International Narcotics Control Strategy Report. 2016. Retrieved from https:// www.state.gov/j/inl/rls/nrcrpt/2016/index.htm.

8. Geib R. Armed violence in fragile states: Low-intensity conflicts, spillover conflicts, and sporadic law enforcement operations by third parties. International Review of the Red Cross. 2009, 91, 127-142.

9. George J. State failure and transnational terrorism: an empirical analysis. Journal of Conflict Resolution, 2016, 62(3), 471-495.

10. Global Policy Forum. Explanatory note of the Secretary-General: Peacebuilding Commission (April 
17, 2005). Retrieved from: https://www.globalpolicy.org/component/content/article/226-initiatives/32293explanatory-note-of-the-secretary-general.html

11. Gordon D. The Global Infectious Disease Threat and Its Implications for the United States. 2000. Retrieved from https://fas.org/irp/threat/nie99-17d.htm.

12. Haass R. Sovereignty: Existing rights, evolving responsibilities. US Department of state, 2003. Retrieved from https://2001-2009.state.gov/s/p/rem/2003/16648.htm

13. Helman, G.D. \& Ratner S.R. Saving Failed States. «Foreign Policy», (Winter, 1992-1993), 89, 3-20.

14. Holsti O.R. Theories of International Relations. Making American Foreign Policy. Taylor and Francis Group, New York, 2006, 313-344.

15. Humanitarian Country Team. Humanitarian needs overview Yemen - 2016. Retrieved from http:// reliefweb.int/sites/reliefweb.int/files/resources/YEMEN\%202017\%20HNO_Final.pdf.

16. Iqbal Z, Starrm H. Bad neighbors: Failed states and their consequences. Conflict Management and Peace Science, 2008, 25(4), pp. 315-331.

17. Lisanti D. Do failed states really breed terrorists? An examination of terrorism in Sub-Saharan Africa comparing statistical approaches with a fuzzy set qualitative comparative analysis. 2010. Charleston: CAPER Workshop.

18. Marshall M. Polity IV Project. Political Regime Characteristics and Transitions, 1800-2002. Retrieved from http://www3.nd.edu/ mcoppedg/crd/PolityIVUsersManualv2002.pdf.

19. McGowan, P.J. Coups and conflict in West Africa, 1955-2004: Part II, empirical findings. 2006. Armed Forces and Society, 32(2), 234-253.

20. Patrick S. Failed states and global security: Empirical questions and policy dilemmas. International Studies Review, Winter, 2007, 9(4), 644-662.

21. Piazza J. Transnational terror and human rights. International Studies Quarterly, 2009, 53, 125-148.

22. Renner, M. Disarming postwar societies. Washington: Worldwatch Institute, 2005.

23. Rotberg, R. Failed states, collapsed states, weak states: Causes and indicators. Wilson Center, Washington, D.C., 2011, 1-25.

24. SIPRI. Yearbook 2016. Retrieved from https://www.sipri.org/sites/default/files/YB16-SummaryENG.pdf.

25. Small Arms Survey. 2015 Yearbook. Retrieved from http://www.smallarmssurvey.org/publications/ by-type/yearbook/small-arms-survey-2015.html.

26. State Failure Task Force Report: Phase III Findings, 2000. Retrieved from: http://www.raulzelik.net/ images/rztextarchiv/uniseminare/statefailure $\% 20$ task\%20force.pdf.

27. Takeyh R. and Gvozdev, N., Do terrorist networks need a home? The Washington Quarterly, 2002, $25,97-108$.

28. The World Bank. Country Policy and Institutional Assessment. Retrieved from http://siteresources. worldbank.org/EXTCPIA/Resources/CPIA_eval.pdf.

29. UN. Report of the Secretary-General in Larger Freedom. 2005. Retrieved from http://www.un.org/en/ ga/search/view_doc.asp?symbol=A/59/2005.

30. USAID. Foreign aid in the national interest promoting freedom, security, and opportunity. 2002. Retrieved from http://pdf.usaid.gov/pdf_docs/Pdabw901.pdf.

31. Vayrynen R. Complex humanitarian emergencies: concepts and issues, In: Nafziger, E.W., Stewart, F. \& Va"yrynen, R. eds. War, hunger, and displacement: the origins of humanitarian emergencies. Oxford: Oxford University Press. 2000.

32. World Bank. Evaluation of World Bank Support to Low-Income Countries Under Stress (LICUS): An approach paper. Retrieved from http://documents.worldbank.org/curated/en/205311468327334849/ Evaluation-of-World-Bank-support-to-Low-Income-Countries-Under-Stress-LICUS.

33. Young W. Spillover from the conflict in Syria: An assessment of the factors that aid and impede the spread of violence. RAND Corporation. 2014. Retrieved from http://www.rand.org/content/dam/rand/pubs/ research_reports/RR600/RR609/RAND_RR609.pdf 